\title{
UNEMPLOYMENT INSURANCE AND PRECAUTIONARY SAVING
}

Eric M. Engen

Jonathan Gruber

Working Paper 5252

\section{NATIONAL BUREAU OF ECONOMIC RESEARCH 1050 Massachusetts Avenue \\ Cambridge, MA 02138 \\ September 1995}

The views expressed are those of the authors and do not necessarily reflect those of the Board of Governors, the other members of its staff, or the National Bureau of Economic Research. We are grateful to Julie Berry and Raaj Chitaley for exceptional research assistance, and to Jan Eberly, Jerry Hausman, Steve Pischke, Jim Poterba, Andrew Samwick, Louis Sheiner, and seminar participants at the University of Chicago, the Federal Reserve Board, Harvard University, Michigan State University, the University of Minnesota, and the NBER for helpful comments. Gruber acknowledges financial support from the National Institute on Aging. This paper is part of NBER's research programs in Public Economics and Labor Studies.

(C) 1995 by Eric M. Engen and Jonathan Gruber. All rights reserved. Short sections of text, not to exceed two paragraphs, may be quoted without explicit permission provided that full credit, including $(\odot)$ notice, is given to the source. 


\title{
UNEMPLOYMENT INSURANCE AND PRECAUTIONARY SAVING
}

\begin{abstract}
We consider both theoretically and empirically the effect of unemployment insurance (UI) on precautionary savings behavior. Simulations of a stochastic life cycle model suggest that increasing the generosity of UI will substantially lower the asset holdings of the median worker, and that this effect will both rise with unemployment risk and fall with worker age. We test these implications by matching data on potential UI replacement rates to asset holdings in the Survey of Income and Program Participation (SIPP). Our empirical results are quite consistent with the predictions of the model. We find that raising the replacement rate for UI by 10 percentage points lowers financial asset holdings by 1.4 to $5.6 \%$, so that UI crowds out up to one-half of private savings for the typical unemployment spell. We also find that this effect is stronger for those facing higher unemployment risk and weaker for older workers.
\end{abstract}

Eric M. Engen

Board of Governors of the Federal

Reserve System

20th and Constitution Avenue

Mail Stop 83

Washington, DC 20551
Jonathan Gruber

Department of Economics MIT

50 Memorial Drive

Cambridge, MA 02138 and NBER 
The concept that some household saving may be undertaken as a precaution for a "rainy day" has long been recognized in the savings literature. Recent simulation studies suggests that precautionary saving is a significant, and perhaps the most important, determinant of individual wealth accumulation. Empirical studies of precautionary saving have produced somewhat more mixed conclusions, however. This empirical ambiguity may stem, at least in part, from the difficulty in identifying and measuring exogenous indicators of the income uncertainty facing an individual.

A key element of the uncertainty in future income for working households, and thus a potential determinant of precautionary saving, is the risk of job loss. This uncertainty is mitigated in the U.S. by the presence of unemployment insurance (UI), which replaces (on average) 45 percent of a covered worker's lost earnings for up to 26 weeks after job loss. A natural prediction of precautionary saving models is that this type of income insurance should reduce wealth accumulation. Furthermore, the extent of the income insurance available to workers who are unemployed varies exogenously with the generosity of the UI system in their state of residence. Thus, differences across workers in UI benefits provides a natural source of variation for testing the presence of the precautionary savings motive.

The purpose of this paper is to assess, both theoretically and empirically, the effect of changes in unemployment insurance generosity on household wealth accumulation. We begin by analyzing a stochastic life-cycle model in which risk-averse, prudent individuals face uncertainty over both their employment status and their wage, conditional on employment. Income uncertainty stemming from temporary unemployment risk is mitigated by an unemployment insurance system which is financed by a mandatory payroll tax. Simulations of the model show that government provision of insurance firr idiosyncratic unemployment risk that is not insurable in the private market can cause a considerable decline in savings: for the median household, raising the UI benefit replacement rate by 10 percentage points lowers median wealth-income ratios by about 7 percent. The effects of UI on asset accumulation are shown to vary systematically according to individual characteristics, such as age and unemployment risk, as well as the generosity of the UI benefit replacement rate. We also embed the model in an 
overlapping-generations, general equilibrium framework which allows for simulating the feedback effects of the higher rate of return to capital and lower wages caused by a smaller capital stock; these effects only partially mitigate the negative asset accumulation effects of UI.

In the second part of our analysis, we use household-level data from the Survey of Income and Program Participation (SIPP) to estimate the crowd-out effect of UI on precautionary saving. ${ }^{1}$ We employ a rich reduced-form empirical specification which controls for many potential determinants of savings behavior which might be spuriously correlated with unemployment insurance generosity such as wages and fixed location effects. We find that there is a significant crowd-out effect of UI generosity on financial asset holdings: increasing the benefit replacement rate by 10 percentage points lowers financial wealth-to-income ratios by 1.4 to 5.6 percent. This crowdout of private savings is 20 to 53 percent as large as the income loss sustained by the average unemployed worker. This effect is strongest for those facing the greatest risk of unemployment and for younger workers, which is consistent with the predictions of the precautionary-saving model. Overall, our empirical results support the premise that the precautionary motive is an important determinant of individual savings behavior; although the unemployment insurance system may raise individual welfare, it also substantially reduces the savings of the median worker.

The paper proceeds as follows. In Part $\mathrm{I}$, we provide a brief overview of the related previous literature on precautionary savings behavior. Part II discusses the structure of the stochastic life-cycle simulation model. Part 111 presents simulation results analyzing the saving effects of UI in the model. Part IV outlines our empirical strategy. Part V presents the basic results, while Part VI presents some extensions. Part VII concludes.

\footnotetext{
${ }^{1}$ While previous work has examined the effect of UI on unemployment durations (e.g. Meyer, 1990), layoff propensities (e.g. Topel, 1983), and consumption (Hamermesh, 1982; Gruber, 1994), there has been no previous empirical examination, that we are aware of, of the savings effects of UI. Related historical analysis is presented by Palumbo (1992); he found that membership in trade unions and benefit societies, which provided some measure of private unemployment insurance, lowered the odds of saving for working households in Maine in 1890.
} 
I. Related Previous Literature on Precautionary Savings and Social Insurance

\section{A. Simulation Studies}

There is a sizeable literature which has considered the role of precautionary savings; see Deaton (1992) and Browning and Lusardi (1995) for reviews of recent developments. A number of recent studies have simulated the role of income uncertainty in individual savings decisions, and find that precautionary saving can explain a sizeable portion, and perhaps the majority, of U.S. savings. ${ }^{2}$

The interaction of social insurance programs, other than UI, with precautionary savings motives has been investigated as well. Sheshinski and Weiss (1981), Abel (1985), Kotlikoff, Shoven, and Spivak (1987), and Hubbard and Judd (1987) show that, in partial equilibrium models with a functioning capital market but no annuity market, Social Security can significantly decrease precautionary saving when lifespan is uncertain, while increasing individual welfare. ${ }^{3}$ Hubbard, Skinner, and Zeldes $(1994,1995)$ develop a simulation model of precautionary savings with uncertainty concerning earnings, uninsured necessary medical expenditures, and lifespan, and include a minimum level of consumption provided by a means-tested social insurance program. They show that social insurance can significantly reduce savings through two mechanisms: by mitigating the need for precautionary savings through the provision of a welfare safety net for consumption, and by taxing away individual savings through means-testing to qualify for government assistance. Kotlikoff's (1988) simulation analysis of public health insurance provides similar conclusions.

${ }^{2}$ See Skinner (1988), Zeldes (1989), Caballero (1991), Deaton (1991), Carroll (1993), Carroll and Samwick (1993), Engen (1993b), and Hubbard, Skinner, and Zeldes (1994). Aiyagari (1994a) has suggested that the effects of income uncertainty and precautionary saving on aggregate saving are substantially mitigated by general equilibrium adjustments. We consider this point in Part III.

${ }^{3}$ This precautionary savings reduction and welfare increase is somewhat mitigated after accounting for general equilibrium effects; with borrowing constraints, the savings reduction is mitigated further and the welfare increase can be reversed (Hubbard and Judd, 1987). Samwick (1994) demonstrated that the negative offset to saving from Social Security will be reduced if precautionary savings for income uncertainty comprises most of the saving undertaken by workers subject to the Social Security payroll tax. 
In work more closely related to this study, Hansen and Imrohoroglu (1992) simulate the potential welfare benefits of an unemployment insurance program in a dynamic general equilibrium model with infinitely-lived agents whose only motivation for saving in a non-productive asset is to buffer unemployment spells. They find that welfare can improve with the introduction of UI, and saving drops to zero with the optimal benefit replacement rate and no moral hazard."

While providing an interesting analysis of optimal UI benefits determination, Hansen and Imrohoroglu's model potentially overstates the degree to which UI crowds out savings in the U.S., for two reasons. First, since the only motivation for savings in the model is to buffer unemployment shocks, the level of asset accumulation is unrealistically low. Asset-income ratios generated by their model are 0.5 or less, without UI, and as low as zero with a UI program; in fact, the aggregate wealth-income ratio in the U.S. is above 3, and the median household wealth-income ratio tabulated from the 1992 Survey of Consumer Finances is 1.8. Second, the UI program in their model misrepresents the structure of the program in the U.S. in ways which will overstate its impact on precautionary savings. In their model, a worker can receive UI benefits indefinitely, while in practice benefits are generally limited to 6 months; and the UI benefit replacement schedule in their model is a constant proportion of pre-unemployment wages, which ignores actual minimum and maximum UI benefit levels. As a result of these shortcomings, the (percentage) effect of an unemployment insurance system on savings in their model is unrealistically large.

\section{B. Empirical Studies}

Econometric investigations to empirically assess the role of precautionary savings have reached mixed conclusions. Much of the empirical difficulties facing previous studies are related to identifying

The optimal benefit replacement rate and welfare are found to vary substantially depending upon the degree of moral hazard. Other theoretical studies of optimal UI benefits include Bailey (1978), Fleming (1978), Shavell and Weiss (1979), Mortensen (1983), Easley, Kiefer, and Possen (1985), Atkeson and Lucas (1995), and Davidson and Woodbury (1995). 
and measuring exogenous indicators of income uncertainty facing a household. Testing the precautionary saving model requires constructing a measure that both captures income uncertainty and is uncorrelated with other characteristics that may influence saving. These requirements have proved difficult to meet for most previous empirical approaches.

Early attempts to find supporting evidence for the precautionary motive are in Fisher (1956) and Friedman (1957), as well as Skinner (1988), who tabulated saving rates by occupation. While Fisher and Friedman find some evidence that individuals save more when in occupations assumed to have riskier income - consistent with the precautionary saving hypothesis - Skinner found that the highest risk occupations, the self-employed and sales workers, had lower rates of savings. However, occupation is an extremely crude measure of consumer uncertainty, and, as Skinner notes, if less risk-averse individuals self-select into occupations with riskier incomes then the precautionary saving theory does not necessarily imply that people in these occupations will save more.

The recent literature has expanded on this strategy to consider in more detail the variation in risk facing individuals according to their individual and job characteristics, with mixed results. ${ }^{5}$ One set of studies has examined the effect of uncertainty on consumption patterns. Dardanoni (1991), using data on British households, found average consumption across occupation and industry groups to be significantly lower when income variance was greater. But Dynan (1993) finds that the quarterly variance of consumption expenditures is not a significant predictor of the quarterly growth rate of consumption,

\footnotetext{
${ }^{5}$ A different approach is pursued by Guiso, Jappelli, and Terlizzese (1992). Using data on Italian households, they find that consumption is only slightly lower, and asset accumulation only slightly higher, for consumers reporting a greater subjective variance for their next year's income. But this subjective variance may not be an accurate estimate of the longer-horizon uncertainty required by the theory. Their estimates of the risk facing the individual are only one-tenth to one-fifth as large as the estimates of income uncertainty from U.S. panel data. Furthermore, individual assessments of a given level of uncertainty may also be correlated with tastes for savings, so that there may be little predictive power for the effect of an exogenous change in the uncertainty facing all persons. This also is a potential problem with the study by Lusardi (1993), which also uses Italian data and finds a somewhat bigger wealth effect than Guiso et al. using a subjective earnings variance measure.
} 
when this variance is instrumented by education, occupation, or industry. And Carroll (1994), using U.S. data from both the Panel Study of Income Dynamics (PSID) and the CES, finds that measures of the coefficient of variation or the variance of future income uncertainty has no statistically significant effect on current consumption, although a rise in Kimball's (1990) "equivalent precautionary premium," which can only be calculated under certain restrictive assumptions, is found to significantly decrease current consumption.

There are important problems with these approaches, however. For example, the cross-sectional variance of income used by Dardanoni is not necessarily related to the time-series variation of income required by the precautionary saving model. Furthermore, it is likely that Dynan's innovative approach asks too much of the limited, available data. In her data, the Consumer Expenditure Survey, consumption growth rates are only available for 3 quarters, and a three-period measure of the variance is quite likely to be an extremely noisy measure of actual quarterly reevaluations of expected lifetime income. Finally, as Carroll and Samwick (1994) note, the theoretical relationship between current consumption, or consumption growth, and income uncertainty can be quite subtle in the precautionary saving model.

On the other hand, there is a clearer theoretical implication for the relationship between uncertainty and wealth: greater income uncertainty increases precautionary savings. ${ }^{6}$ Two recent studies have considered the effect of uncertainty on wealth holdings. Kazarosian (1994) finds that the variance of a household's income is a positive predictor of wealth-income ratios, consistent with precautionary saving. This result, however, may simply reflect the fact that a positive (negative) transitory income shock leads to a current increase (decrease) in wealth, which is also consistent with some consumption models that do not feature precautionary saving. Carroll and Samwick (1994) surmount this problem hy

'Is a standard precautionary savings model, for example, individuals facing a higher variance if lifetime income will have lower consumption at young ages but higher consumption at older ages; they will have a higher ratio of wealth-to-income at all ages, however. 
instrumenting the variance of income by the education and occupation of the household head. They also find that income uncertainty is an important predictor of household wealth-income ratios. However, their results are somewhat sensitive to whether older workers and the self-employed and farmers are included in the sample.

Most importantly, none of the above cited studies has necessarily been able to meet the second criterion for a meaningful measure of uncertainty: that it be uncorrelated with other household characteristics that determine savings behavior. Education, occupation, and industry are all, to some extent, choice variables that reflect the same underlying tastes that drive wealth accumulation. Thus, it is difficult to prove that these findings are not driven by a correlation between the uncertainty measure and an omitted taste parameter.

\section{Theoretical Framework}

In this section, we examine unemployment insurance in the context of a stochastic life-cycle simulation model.' The model in this paper extends the standard life-cycle framework to include income

${ }^{7}$ In related work, Guiso, Jappelli, and Terlizzese (1994) find that income risk significantly affects household asset portfolio choice by reducing the demand for risky assets, which is consistent with a precautionary saving model. Starr-McCluer (1994) finds that having health insurance reduces households' financial asset holdings, once the endogeneity of health insurance coverage is taken into account. Guiso and Jappelli (1994) provide empirical evidence in support of the proposition that people facing higher uninsurable risk buy more insurance against other risks that are insurable. Levin (1995) studies how uncertainty about medical expenses and government health programs (i.e., Medicare and Medicaid) affects the demand for health insurance.

8 There are results in related literatures, using potentially more plausible identification of risk, which lend support to the precautionary motive. Skinner (1985), Hurd (1989), and Engen (1993a) have shown that household consumption growth is significantly sensitive to mortality rates, which is consistent with precautionary saving because of lifespan uncertainty and the absence of perfect annuity markets. And Fishback and Kantor (1994) find that increases in the generosity of insurance for on the job injuries in the early 20th century lowered household savings.

'See Engen $(1993 a, b)$ for further details on the estimation and specification of a related model and its solution and saving properties. 
risk arising from two sources: a positive probability of unemployment, and uncertainty about wages, conditional on employment. Individuals are forward-looking, risk-averse and prudent, ${ }^{10}$ and therefore save as a precaution against downturns in future earnings as well as saving for retirement. By utilizing estimates of behavioral and economic characteristics (i.e., preference parameters, stochastic processes), the model allows us to develop testable predictions for the response of saving behavior to governmentprovided unemployment insurance.

\section{A. Consumer Preferences}

An individual enters the model at age 21 and lives with certainty until age 75 . In period $t$, an individual chooses consumption, $\mathrm{C}_{\mathfrak{}}$, and makes a contingency plan for future consumption, $\left\{C_{t+1}, \ldots, C_{D}\right\}, "$ to maximize expected lifetime utility (ELU):

$$
E L U_{t}=E_{t}\left[\sum_{j=t}^{D}(1+\delta)^{t-j} U\left(C_{j}\right)\right]
$$

$E_{2}$ is the expectations operator conditional on information available at period $t, D$ is the period corresponding to the maximum possible lifespan, $\delta$ is the rate of time preference, and $U(\cdot)$ is the instantaneous utility function. The model is calibrated at a quarterly frequency to allow for unemployment spells and UI eligibility periods to be less than a year.

Several assumptions make the model tractable while still capturing important elements of household saving decisions for evaluating the effects of UI benefits. First, individuals do not have an explicit bequest motive. Second, labor supply and retirement decisions are assumed to be exogenous. Third, utility is assumed to be separable over time, and separable within a time period for consumption and leisure; in addition, private consumption and leisure are assumed to be completely separable from

\footnotetext{
${ }^{10}$ Prudence refers to the propensity to save as a precaution against uncertainty (Kimball, 1990).

"Consumption, actual and planned, is restricted to be non-negative: $C_{t+j} \geq 0 \quad \forall j=0, \ldots, D-t$.
} 
any government-provided good. Finally, the utility function for private consumption is assumed to exhibit constant relative risk aversion (constant intertemporal elasticity of substitution), which implies that risky labor income leads to precautionary saving:

$$
\begin{aligned}
U\left(C_{\imath}\right) & =C_{\imath}^{1-\gamma} /(1-\gamma) & & \text { if } \gamma \neq 1, \\
& =\ln \left(C_{\imath}\right) & & \text { if } \gamma=1 .
\end{aligned}
$$

where $\gamma$ denotes the relative risk aversion coefficient $(\gamma>0)$ and the intertemporal elasticity of substitution for consumption is equal to $1 / \gamma .^{12}$

\section{B. Budget Constraint}

The choice of consumption depends on the consumer's financial wealth at age $t, W_{t}$. Wealth after receiving net labor income, $\mathrm{Y}_{\mathfrak{t}}^{*}$ (if employed), net $\mathrm{UI}$ benefits, $\mathrm{B}_{\mathrm{t}}^{*}$ (if unemployed and eligible for benefits), pension income, $P_{t}^{*}$ (if retired), and net (certain) capital income, $\left(W_{t-1}-C_{t-1}^{*}\right) r^{*}$, but before consuming $C_{1}$, is determined by the wealth transition equation:

$$
W_{t}=\left[W_{t-1}-C_{t-1}^{*}\right]\left(1+r_{t}^{*}\right)+\left(1-R_{t}\right)\left[S_{t} Y_{t}^{*}+\left(1-S_{t}\right) B_{t}^{*}\right]+R P_{p}
$$

where after-tax values of consumption and income are determined as:

$$
C_{i}^{*}=C_{t}(1+\tau), r_{i}^{*}=r_{t}(1-\tau), Y_{i}^{*}=Y_{i}\left(1-\tau^{\eta}\right)-\min \left(\tau^{p} Y_{p} \tau^{p} \bar{Y}\right) \text {, and } B_{i}^{*}=B_{t}\left(1-\tau^{\eta}\right) \text {. }
$$

with general taxes on consumption, interest income, and labor income represented by $\tau$, $\tau$, and $\tau^{y}$. respectively, and a payroll tax to finance UI, $\boldsymbol{t}^{\circ}$. Since the consumer's lifespan is certain and a consumer

\footnotetext{
${ }^{12}$ The structural preference parameters for this stochastic life-cycle model are estimated using household panel data in Engen (1993a). Estimates of the intertemporal elasticity of substitution, $1 / \gamma$, are in the range of 0.30 and 0.38 which implies a risk aversion coefficient, $\gamma$, between 2.6 and 3.3 . Estimates of the time preference rate, $\delta$, are in the range of 0.04 to 0.08 . For the simulations of the model, these estimates provide a range of estimates for $\gamma$ and $\delta$ that are consistent with values used in many other studies.
} 
is not allowed to die in debt, a constraint on the consumer's wealth is $W_{D+1} \geq 0 .{ }^{13}$

Exogenous and certain labor force status is denoted by $R_{t}$, with $R_{t}=1$ if the consumer is retired and out of the labor force and $R_{t}=0$ if the individual is in the labor force. Exogenous but uncertain employment status (conditional on being in the labor force) at time $t, S_{t}$, is equal to one $\left(S_{t}=1\right)$ if the consumer is employed, and is equal to zero $\left(S_{t}=0\right)$ if unemployed. Employment status is assumed to follow a first-order Markov process:

\begin{tabular}{|c|c|c|c|}
\hline & & \multicolumn{2}{|c|}{ previous period $(t-1)$} \\
\hline & & employed & unemployed \\
\hline \multicolumn{2}{|c|}{ current period. (t) } & $S_{t-1}=1$ & $S_{t-1}=0$ \\
\hline employed & $S_{t}=1$ & $p_{i}^{1}$ & $\left(1-p_{t}^{0}\right)$ \\
\hline unemployed & $S_{t}=0$ & $\left(1-p_{t}^{1}\right)$ & $\mathrm{p}_{\mathrm{t}}^{0}$ \\
\hline
\end{tabular}

It is assumed that the worker knows the actual probabilities in this stationary, homogenous Markov process. ${ }^{14}$ The magnitude of the probability of being unemployed and receiving zero labor income will significantly affect the amount of precautionary saving undertaken. The baseline probability of being employed given employment in the previous period is set to $\mathrm{p}^{1}=.97$, and the probability of remaining unemployed the next quarter if unemployed in the current quarter is $\mathrm{p}^{0}=.35$. These probabilities were

\footnotetext{
${ }^{13}$ Nonsatiation and a certain time of death will make this constraint an equality. Also, any borrowing restrictions in this model refer to consumption loans, not collateralized loans for houses, cars and other durables which comprises the vast majority of actual lending. Note that if there is a positive probability of being unemployed in every period and being unemployed results in zero labor income, then a consumer will never want to borrow if marginal utility goes to infinity as consumption goes to zero (which is the case for constant relative risk aversion). With UI, a consumer may want to borrow against the small certain component of expected UI benefits, but borrowing against UI benefits is not allowed in the model in order to mirror actual lending practices.

${ }^{14}$ In particular, we do not allow these parameters, or labor supply more generally, to be a function of the generosity of the UI system. There is an uncertain relationship between UI benefit generosity and the probability of becoming unemployed (Feldstein, 1978; Topel, 1983; Anderson and Meyer, 1994), but there is strong evidence that more generous benefits lengthen unemployment durations (Meyer, 1990). Endogenizing $\mathrm{p}^{1}$ or $\mathrm{p}^{0}$ would greatly complicate the model, however.
} 
calculated by the authors using monthly data on employment and unemployment for 1984-1987 from the Panel Study of Income Dynamics.

Net UI benefits are denoted by $B_{\imath}^{*}$ where $B_{\imath}$ is gross UI benefits and $\tau^{y}$ is the personal income tax rate. UI benefits are considered taxable income by the personal income tax, which is true for most workers after 1982 and all workers after 1986. If unemployed $\left(S_{t}=0\right)$ then the worker will receive gross UI benefits $B_{\imath}$ which are a function of their previous labor earnings: $B_{t}=\left\{\min \left[\bar{B}, \max \left(\underline{B}, \theta Y_{t \cdot 1}\right)\right]\right\}$. The gross replacement rate for UI benefits is denoted by $\theta$, with the maximum UI benefit level equal to $\bar{B}$ and the minimum benefit level equal to $\underline{B}$. However, if a worker remains unemployed for two periods, but the benefit duration is only one period, then $B_{t}=0$.

The UI formula replacement rate, $\theta$, is set initially set equal to 0.50 of the previous period level of earnings so long as the benefit is above a minimum level of $\$ 325 /$ quarter and below a maximum level of $\$ 3,900 /$ quarter. The average replacement rate is then slightly below $\theta$ as more UI beneficiaries are constrained by the maximum benefit level than bolstered by the minimum. ${ }^{13}$ The taxable maximum for earnings is set to be $\$ 7000$, the current maximum for the Federal Unemployment Tax. Unemployment benefits are available for 2 quarters, consistent with the 26 week limit facing most workers in the U.S. ${ }^{10}$

Net labor earnings, if employed, are denoted by $Y_{i}^{*}$ with the payroll tax rate used to finance UI benefits, $\boldsymbol{\tau}^{+}$, and the personal income tax rate, $\tau^{y}$, both assessed on labor income. However, the payroll tax is levied only on labor income up to a limit of $\bar{Y}$. Tax revenue from the income tax and a sales tax on consumption is used by the government to tinance both a government-provided consumption good

\footnotetext{
${ }^{15}$ This average is quite similar to the average replacement rate, and is almost exactly equal to the median replacement rate, in our SIPP sample.

${ }^{16}$ In practice, benefit duration can vary as a function of several factors: earnings over the previous 5 quarters; state extensions of benefits when unemployment exceeds a "trigger" level; and federsl extension of benefits in national recessions. We show the effects of varying UI benefits durations belou
} 
(assumed to be separable in the consumer's utility function) and Social Security benefits. ${ }^{17}$ The individual receives a certain stream of pension income, $P_{t}$, when retired until death. This income represents both net payments from Social Security and a private pension; these are lump sum payments which are exogenous to the individual's own earnings history. ${ }^{18}$

Conditional on being employed, gross labor earnings are $Y_{1}=w_{t} z_{1} h$, where $w_{t}$ is the wage rate per effective labor unit in period $t, z_{1}$ is an exogenous age-specific human capital adjustment factor, and the exogenous number of labor hours supplied is $h$. Individuals age 21-65 work h hours if employed $\left(R_{1}=0\right.$, $\left.S_{t}=1\right)$, and they are retired $\left(R_{t}=1\right)$ during ages 66 to $D$. The human capital adjustment factor $z_{t}$ allows individuals to earn more or less (on average) than other workers at time $t$ because of different productivity/skill levels among individuals of different ages. However, $z_{\imath}$, and therefore the mean level of labor earnings, is the same for all individuals within an age cohort.

The log of labor earnings, $y_{t}=\ln \left(Y_{2}\right)$, is assumed to be normally distributed around a mean level of earnings. To capture the persistence of observed earnings shocks over time, the error structure for the log of labor earnings is specified as an AR(1) process. Appendix A provides details concerning the specification of the stochastic labor earnings process, as well as a discussion on solving the model.

A key assumption in this model is that there are no private markets for insuring riskiness in wages or unemployment prospects, inducing the individual to save as a precaution for these risk. This assumption follows the literature which motivates the existence of social insurance programs through market failures such as adverse selection or moral hazard (ie. Diamond, 1977). There may in fact be market and non-market insurance available to individuals, such as the labor supply of spouses, support

\footnotetext{
${ }^{17}$ One can think of part of what is designated as the income tax on wages as consisting of a SS payroll $\operatorname{tax}$.

12The sum of pension and SS benefits replace 41 percent of the average of the three highest expected mean years of wages. This replacement rate is consistent with estimates in Boskin and Shoven (1987). Real pension income is assumed to decline by 1 percent, reflecting that private pensions only partially cover (on average) cost of living increases.
} 
from friends, and other social insurance programs. But empirical work by Hamermesh (1982), Cochrane (1991), Nelson (1994), and Gruber (1994) suggests that these alternatives provide much less than full consumption insurance against adverse income or unemployment shocks, so that precautionary savings remains an important consumption smoothing device.

\section{UI Policy Simulations and Results}

\section{A. UI and Individual-level Saving}

Table 1 shows the effect of a UI program on individual median asset-to-income ratios, for individuals age 25 to 64 , and expected consumer welfare in the stochastic life-cycle model. The model generates a median asset-income ratio of 3.61 for working individuals in the absence of Ul. The mean asset-income ratio, not shown in the table, is somewhat higher (4.32), reflecting the skewed nature of wealth accumulation. The effects of UI on median and mean asset ratios are quite similar, so the results for means are not reported in Table 1. Precautionary saving represents approximately 80 percent of total saving in this initial scenario.

Introducing a UI program dramatically reduces saving accumulation; the median asset-income ratio falls by $38 \%$ to $2.25 .{ }^{19}$ At the same time, by insuring the otherwise uninsurable risk of job loss, UI raises the expected utility of a risk-averse, prudent consumer by 8.3 percent. ${ }^{20}$

The next four rows of Table 1 alter the risk-aversion coefficient and time preference rate used in our baseline simulations. The absolute effects of UI are larger for more risk averse workers, while

\footnotetext{
${ }^{19}$ With UI coverage, the median asset-income ratio is a little higher than a comparable median assetincome ratio of 1.8 in the 1992 Survey of Consumer Finances.

${ }^{20}$ It is important to note that this welfare gain ignores several additional effects of unemployment insurance coverage, such as additional welfare costs through increased unemployment durations and increased temporary layoffs, and additional (potential) welfare gains through improved job matches arising from subsidized search. The welfare gains reported in Table 1 reflect only the gains in terms of smoothing consumption. See Gruber (1994) for a further discussion of the limitations of this type of model for doing welfare analysis of UI.
} 
the rate of time preference has little absolute effect. Overall, the results are fairly robust to variations in these key parameters.

In rows six and seven, the probability of being unemployed $\left(1-\mathrm{p}^{1}\right)$, conditional on currently being employed, is changed from the initial simulation value of 3 percent. For the median 25-64 year old, the reduction in the asset/income ratio from introducing $\mathrm{UI}$ is larger by 15 percentage points of income at a probability of unemployment of 4 percent than at a probability of unemployment of 2 percent. Thus, in our empirical analysis, we should expect to find that higher unemployment risk should be positively correlated with a higher UI crowd-out effect. However, note that at the same time, the model suggests that UI offers a larger welfare gain when unemployment risk is higher.

Table 2 considers the variation in individual saving responses to the introduction of UI along the life cycle. As workers age, their savings will respond less (in percentage terms) to the presence of UI for two reasons. First, older workers will have generally been able to accumulate a large stock of precautionary saving, thus reducing the savings effects of UI on the margin. Second, older workers will have resolved much of the inherent uncertainty in lifetime wages and employment and thus face fewer years in which they can be unemployed. As a result of these factors, the effect of UI falls monotonically with age in the model. For those above 45 , the effect of introducing UI is only about half as large as for those below 45 .

Table 3 illustrates the effects of changing the policy parameters of the UI system. The first row shows the median asset-income ratio for workers age 25-64; we also report the average UI benetit replacement rate and payroll tax rate necessary to finance the UI program. The following rows also show the welfare change relative to the baseline parameterization. As noted above, the average replacement rate in this baseline specification corresponds closely to the median replacement rate in our SIPP sample. As the slope coefficient $\theta$ rises, increasing the generosity of the UI system, there is a decrease in asset accumulation and a rise in welfare. Increasing the average replacement rate by 10 percentage points 
decreases the median asset-income ratio by 0.15 percentage points of income, or a change of 6.7 percent. Lowering the benefit replacement rate by 11 percentage points yields a slightly larger percentage decline of 7.1 percent. Although not shown on the table, continually lowering the benefit replacement rate gives larger proportional increases in the asset-income ratio. This is because the marginal utility of the additional income, and thus the reduced need for precautionary savings, is lower as UI replaces a larger share of pre-unemployment resources. But even in the range of replacement rates found in the data, increasing UI generosity crowds out personal capital accumulation.

The final two rows demonstrate the effect of changing the duration of UI benefits (at the baseline $\theta=0.5$ ). Raising duration to one year further reduces the need for precautionary savings, lowering wealth accumulation even more relative to the baseline, and increasing welfare. If benefits only last for onequarter, there is a reverse effect; in this case, wealth accumulation is reduced by 98 percentage points of income relative to the no UI baseline, while savings are higher by 38 percentage points of income relative to the UI baseline of two quarters of coverage.

\section{B. UI and Aggregate Saving}

Before moving to the empirical analysis, a final step in our simulation analysis is to incorporate the stochastic life-cycle model into a general equilibrium setting. A general equilibrium model allows for feedback effects of UI policy changes, from changes in savings and capital formation to changes in the rate of return to capital, to wages, and to taxes. These feedback effects are potentially quite important for assessing the net welfare implications of a social insurance program such as Ul. While UI raises welfare by providing insurance against non-diversifiable unemployment risk, it lowers precautionary savings (and the capital stock) for the same reason. In general equilibrium, the lower capital stock raises the rate of return, lowers wages, and increases taxes on this smaller wage base, tempering the rise in welfare and the decline in the capital stock. Ignoring these general equilibrium effects would cause one to overstate the positive effect on welfare and the drop in wealth from the UI program. 
On the other hand, it is difficult to realistically incorporate the aggregate savings implications of the UI program into our modelling framework, which does not capture the cross-sectional richness of savings behavior in the U.S. In fact, UI will have small effects on the high permanent-income individuals who do the bulk of savings, for three reasons: these individuals face less unemployment risk; these individuals have high incomes so that the relatively low maxima on UI benefits limit the value of this program; and these individuals already have sufficient buffer stocks of savings so that small changes in UI generosity will not affect their accumulation decisions (parallel to our argument for older workers above). Thus, simply imposing a GE framework onto our existing model almost certainly overstates the impact of feedback effects on our basic results. Nevertheless, given the potential importance of general equilibrium adjustments, we need to consider their effects.

To do so, we use an overlapping generations framework which requires aggregating over all the individuals in the different age cohorts at a given point in time in order to derive aggregate measures of consumption, saving, and income for the economy. We assume that all uncertainty is idiosyncratic, so that there is no aggregate uncertainty. The government is also required to have a balanced budget in each period. UI is therefore financed on a pay-as-you-go basis, with revenue raised from the payroll tax in a given period spent on UI benefits in that period. In the simulations, the UI benefit replacement rate, $\theta$, along with the minimum and maximum benefit levels, are set exogenously by government policy and then the payroll tax rate is determined endogenously so that aggregate UI benefits are equal to aggregate payroll taxes. Other taxes are also endogenous so as to maintain a constant level of the governmentprovided good. More details are provided in Appendix A (also see Engen, 1994).

In aggregate, the model generates an asset-income ratio of 3.79 in the absence of UI, as shown in the bottom row of Table 1. General equilibrium feedback reduces the decline in the asset-income ratiu in response to UI to only 49 percentage points of income. The decline in average wages also mitigates the welfare enhancing effect of UI on risk-averse consumers; the welfare gains of 2.6 percent of expected 
lifetime income are only about one-third as large as in the partial equilibrium setting. Thus, feedback effects do substantially mitigate the effect of UI on aggregate savings; but the crowdout effects on savings are substantial even in this case.

\section{Part IV: Empirical Strategy}

\section{A. Data}

In order to test some of the implications of the precautionary saving model and further investigate the effect of UI on wealth accumulation, we use the largest annual data set available with information on both wealth and socio-economic characteristics, the Survey of Income and Program Participation (SIPP). The SIPP is a longitudinal survey that follows a large cross-section of individuals over a period of roughly 2 and $1 / 2$ years. Each year a new panel of individuals is introduced, and these persons are interviewed for a series of waves (four month periods) over the coming months. In addition to a core set of questions about the preceding four months in each wave, individuals are asked about their wealth holdings in selected waves. For the panels in the earlier years of the SIPP (1984 through 1986), wealth inventories were collected twice, in the fourth and seventh wave. For 1987 and 1990, there is wealth information only in the fourth wave; there is no data for 1988 and $1989 .{ }^{21}$ As a result, we use wealth information for a total of 8 waves spanning the 1984 to 1990 period.

Our unit of observation in the SIPP sample is the household; since the wealth summary measures are collected only at the household level, we excluded households with more than one family in residence. We select the sample according to the following criterion: the respondent household head must be between age 25 and age 64 , inclusive (in order to avoid the effects of either schooling or retirement on wealth accumulation); they must have some wage and salary earnings from a non-self employment job

\footnotetext{
${ }^{21}$ In 1985, the first interview is actually in the third wave. For 1988 and the seventh wave of 1987 and 1990 , there is some wealth data collected, but it is incomplete and is not comparable to the other waves.
} 
in each wave preceding and including the wave of the wealth survey; ${ }^{22}$ they cannot have changed marital status in the waves preceding and including the wealth observation; and they must report values for some wealth data. The resulting sample has 24,903 observations. $^{23}$

We use two measures of wealth: gross financial and net financial assets. Gross financial assets consist of interest earning assets in banking and other institutions, household equity in stocks and mutual funds, and other assets such as bonds and checking accounts; net assets subtracts off unsecured debt from this total. The former has the advantage that gross asset holdings most closely approximate the steady state stock of accumulated precautionary savings, whereas net assets also reflect short run smoothing through consumption loans. Furthermore, debt holding may not proxy for financial constraint but rather access to debt markets. ${ }^{24}$ On the other hand, changes in unemployment insurance generosity should be reflected in borrowing as well as savings behavior. Thus, it is of interest to examine separately both gross and net asset holdings.

We focus only on tinancial wealth, and not on total household net worth, for two reasons. First, precautionary savings for unemployment should be concentrated in assets which can be liquidated quickly

\footnotetext{
${ }^{2}$ This selection rule allows us to measure the average replacement rate using information on each wave up to and including the wealth wave, as described below. It also avoids using individuals who may have already decumulated their wealth (in a manner correlated with UI generosity) in response to an unemployment spell. On the other hand, it does skew somewhat the representativeness of our sample. We have experimented with the sensitivity of our results by also excluding from our sample individuals who have unemployment spells within a wave (but not lasting an entire wave); this had no effect on our results, suggesting that our sample selection is not seriously biasing our inferences.

${ }^{2}$ Since there are two wealth interviews in $1984-86,5562$ households have two observations for wealth. Deleting either the first or second wealth observation for these households has little effect on the results.

${ }^{20}$ That is, an individual with slightly negative net assets may actually have more precautionary savings than a person with slightly positive net assets, if they have better access to unsecured borrowing and therefore a lower boundary condition on net assets.
} 
in the event of job loss, which may exclude categories such as housing. ${ }^{25}$ Second, non-financial assets have some component of consumption value as well as savings, and this consumption value may respond positively, rather than negatively, to UI generosity. For example, as UI benefits rise, and individuals feel less need for precautionary savings, they may purchase more housing. Thus, we focus only on financial assets, which have no direct consumption value. Of course, there are two costs to this approach: first, we ignore any potential response of non-financial assets to UI generosity; and second, we limit the ability to extend our empirical results to aggregate behavior. We therefore discuss below the effect of expanding our dependent variable to include less liquid measures of wealth as well.

Roughly one-quarter of the households in our data set have imputed wealth information, and the SIPP imputation methodology has been criticized by a number of commentators (Curtin et al., 1989; Hoynes et al., 1995). We therefore exclude imputed values for the majority of our analysis. On the other hand, the probability of imputation is not random; for example, it rises with income (and therefore with wealth). Thus, in analyzing the sensitivity of our results below, we show the results with imputed values included as well. ${ }^{26}$

\section{B. Empirical Framework}

In order to model the effect of UI on wealth accumulation, we estimate regressions of the form:

$$
\text { WEALTH }_{i}=\alpha+\beta_{1} X_{i}+\beta_{2} U_{i}+\beta_{3} \delta_{j}+\beta_{4} \tau_{i}+\beta_{5} w_{i}^{*} \delta_{j}+\beta_{6} w_{i}^{*} \tau_{i}+\epsilon_{i j t}
$$

where $i$ indexes households, $j$ indexes states, and $t$ indexes years. WEALTH is household financial assets

${ }^{25}$ We do not include assets in IRA or Keogh accounts, nor pension assets. The former are potentially liquid, in that individuals can take loans against their assets and they only face a small penalty if they withdraw the assets early, but the ultimate perceived liquidity of these assets remains a point of debate.

${ }^{20}$ Curtin et al. (1989) provide an extensive review of the quality of the SIPP wealth data, relative (1) other household surveys and national aggregates. They find that the SIPP understates the wealth holdings of very high income households and of entrepreneurial assets, but that it is otherwise of equal quality (1) other household surveys. Since we focus on tinancial assets, we avoid the problem of problematic measurement of entrepreneurial holdings. And the fact that wealth is under-reported for the very wealthy should influence our estimation, since we use a robust regression technique which minimizes the intluence of these observations. 
normalized by average household income. The underlying role of both precautionary and life-cycle savings is to maintain a given living standard, so that wealth holdings should be considered relative to some measure of permanent income. This also corresponds directly to the wealth-to-income ratios presented in the previous theoretical section. We proxy for permanent income by an average of earnings over the waves up to and including the wealth wave.

$\mathrm{X}$ is a vector of demographic and economic characteristics of the household or household head/spouse: head age and age squared, sex, marital status, race, and education; spousal education, and an indicator for spousal work in any of the waves up to and including the wealth interview wave; the number of children; family income and its square; and an interactions of family income with age (to capture differential effects of income over the life cycle). UI is the replacement rate for this individual under his or her state/year Ul system; once again, we use the replacement rate, rather than the benefit level, to capture the generosity of UI relative to the baseline living standard. $w_{i}$ is the individual's weekly wage rate, and $\delta_{\mathrm{j}}$ and $\tau_{\mathrm{i}}$ are vectors of state and year specific dummies.

Our key regressor is the unemployment insurance benefits for which the individual is eligible. To create this variable, we have built a simulation program which models each state's UI system for the period 1983-1991. The basis for this program is Employment and Training Administration (various years), which reports semi-annual information on state benefit schedules; in addition, it was augmented by information from a number of states and from Levine (1990). The inputs to the program are the individual's weekly wage in each wave and their number of dependents (in some states). UI benefits are then divided by this weekly earnings variable to calculate the replacement rate. Finally, the replacement rate was averaged over the waves up to and including the wealth interview. In this way, we hope to proxy for permanent differences in UI regimes which affect individuals' long run wealth accumulation decisions.

UI benefits were subsidized by the U.S. tax system in two ways over our time period: tior 
workers in low income families (income below $\$ 12,000$ if single or $\$ 18,000$ if married), UI benefits were exempt from income taxation before 1987; and for all workers UI benefits were exempt from payroll taxes. We adjust our replacement rates to account for the second subsidy, but not the first. This is because an individual's income, and thus their income tax rate, is a function of their wealth holdings (through the returns on those assets). ${ }^{27}$

An important potential problem with this specification is that the replacement rate for an individual may be correlated with omitted tastes for savings. In particular, due to the progressive nature of benefit schedules, replacement rates are a negative function of earnings. At the same time, higher wage workers have higher wealth to income ratios. Thus, if wages are not controlled for in the estimation, there will be a spurious negative correlation between the replacement rate and wealth. Even controlling for wages linearly, however, is not sufficient, since the replacement rate is a non-linear function of wages; in some states this function is quite complicated. Thus, we control for a quartic in wages, which should be sufficient to pick up any nonlinearities in UI benefits schedules, in addition to our quadratic in income. Our results are not sensitive to the inclusion of additional higher order terms in either wages or family income.

A related issue is that the normalization of wealth by average family income introduces a potential dependence between the dependent variable and the UI replacement rate. Measurement error which caused reported earnings to be too high would affect both the wealth ratio (since income would be too high) and the replacement rate (since wages would be too high). We have therefore rerun our basic specifications using log wealth as the dependent variable, which overcomes this problem: there is no

\footnotetext{
${ }^{27}$ The correlation between our post-SS tax replacement rate and the true post-income and SS tax replacement rate is 0.99 , and our results are all very similar if the latter measure is used, since the tix exemption only affected low income households in the first three years of our sample. In order to qualify for UI, individuals must have a (state-specific) minimum level of earnings. To approximate this eligibility criterion, we drop any observation where weekly wages are below the minimum weekly UI benefit fir that state and year.
} 
common element in the dependent and independent variables in this case. The results are similar to those reported below, although the estimated savings response is somewhat larger at the mean level of savings. A problem with this specification, however, is that we lose any information on those with zero or negative wealth holdings; this is especially troublesome in the case of net financial assets (where we lose almost one-half of our observations). We therefore use the wealth/income ratio as the dependent variable for the results reported below.

Given these detailed individual controls, the variation in UI benefits across workers in our sample comes from six sources: changes in UI generosity nationwide over time; differences in average UI benefits across states; changes in average state UI benefits over time; relative differences between high and low wage earners across states (the ratio of replacement rates for high and low wage earners will differ across states according to their relative maxima/minima and the slopes of their benefits schedules); changes in the relative differences between high and low wage earners nationally over time; and changes in these relative differences between high and low earners across states over time. We are concerned that some of these dimensions of variation may not be independent of other considerations which determine individual asset accumulation. Therefore, we augment our regression specification in two ways.

First, we include dummies for each SIPP panel, and interactions between dummies for each year and wage levels. This will control for changes across the SIPP surveys that might be correlated with time trends in UI benefits, as well as changes in the distribution of wealth holdings over time that might be correlated with changes in the progressivity of the UI system. Second, we include a full set of fixed effects for every state, and interactions of those fixed effects with wage levels. ${ }^{28}$ This is important because there may be systematic differences between the states in their UI systems which are correlated with wealth levels in the state. That is, even conditional on the income of state residents, states with

\footnotetext{
${ }^{20}$ The SIPP does not identify all states individually, grouping Iowa, North Dakota, and South Dakota together and Alaska, Idaho, Montana, and Wyoming together; we exclude individuals in these states from the analysis.
} 
more wealth may choose to provide more generous UI benefits. Similarly, states with a more skewed distribution of wealth may provide choose more progressive benefits schedules. These correlations are likely to be fixed over the short time period considered in this analysis, so that state fixed effects and interactions will control for the state-specific omitted factors. ${ }^{20}$

The means of the SIPP data are presented in Tables 4A and 4B. Table 4A presents the means of the covariates included in our model. Twenty-four percent of the sample is female, and thirteen percent is non-white. Roughly three-quarters of the spouses are working. The average real weekly wage is $\$ 418$. The average replacement rate, after SS taxes only, is 43.6 percent of previous wages.

For our wealth measures, we present both the mean and the distribution in Table 4B. Two facts about wealth are immediately apparent. First, the distribution of wealth is highly skewed. In order to account for this, we will use robust regression techniques which first exclude influential outlying observations, then iterate towards a solution by downweighting those observations with larger residuals (Berk, 1990). Second, wealth holdings are quite low for the majority of the working population. The median person in our sample only has sufficient assets to cover less than one month of family income; even the worker at the 75th quantile has financial wealth covering less than 3 months of income. Part of the reason for these low wealth holdings is that we have excluded imputed values; including these values raises the means and medians somewhat, as the second panel of the Table shows. But asset holdings remain quite low even in this case.

\footnotetext{
${ }^{29}$ As with other studies of the effect of UI on behavior, we are unable to completely rule out the possibility that our findings are due to individual migration decisions which are correlated with $\mathrm{UI}$ generosity. There is no empirical evidence on this issue in the context of UI. But past research suggests that the generosity of cash welfare benefits has only a small effect on the migration decisions of potentially eligible females (Walker, 1993), for whom welfare provides a much larger total subsidy than does UI for the unemployed (since UI is time limited and welfare is not).
} 


\section{Part V: Basic Results}

Our basic regression results are presented in Table 5, for both gross and net financial assets. In both cases, there is a significant negative correlation between UI generosity and wealth levels. In the first column, the coefficient indicates that raising the replacement rate by 10 percentage points lowers the gross asset to income ratio by 0.35 percentage points, or $1.4 \%$ at the mean gross financial asset to income ratio. For net financial assets, the replacement rate coefficient is also highly significant, and it is much more sizeable; raising the replacement rate by 10 percentage points would lower mean net savings by $5.6 \% .^{3}$ This suggests that there is a response of borrowing behavior, as well as savings behavior, to UI generosity levels. Thus, our basic empirical results show a strong effect on wealth accumulation from the presence of the UI system, as in the previous theoretical section. ${ }^{31}$

While large in percentage terms, these effects are fairly small when expressed in terms of dollars. We find that raising the replacement rate by 10 percentage points reduces savings by $0.35-0.93 \%$ of income, or $\$ 109$ to $\$ 290$ at the mean income in our sample. This small finding in dollars terms is not surprising given the low wealth holdings of the median family.

A natural comparison is to the dollar income risk faced by a family where the head becomes unemployed. The average person who becomes unemployed spends 13.1 weeks unemployed, so that a 10 percentage point replacement rate rise would increase their income over the unemployment spell by $\$ 547$ at the mean real weekly wage in our sample. ${ }^{32}$ Thus, the crowd-out of savings is $20 \%$ to $53 \%$ as large as the decrease in resources from unemployment. This is an upper bound, however, so long as

\footnotetext{
${ }^{30}$ The sample for net wealth is somewhat smaller due to missing data on uncollateralized borrowing. The change in coefficient across the two columns is not due to the smaller sample when we use net wealth; the coefficient for gross wealth is quite similar in this sample to the full sample result.

${ }^{31}$ We return in the conclusion to discuss the set of issues involved in comparing our empirical results to the magnitudes predicted by the theory.

${ }^{32}$ The unemployment duration figure was provided to us by Patty Anderson, based on tabulations if administrative wage history data.
} 
individuals face the prospect of (and are therefore saving for) more than one unemployment spell in the future. ${ }^{33}$

The control variables generally have their expected signs. Savings is predicted to fall at young ages (below age 29 for both gross and net assets), and rise thereafter (evaluated at the mean income level). Higher education is associated with more savings, while being a female head is associated with more savings, but even more borrowing, for a negative net asset effect. The marital dummy has a negative coefficient, but it cannot be interpreted without consideration of the spousal education and work variables. At the mean values, being married with a non-working spouse is associated with an increase in the asset/income ratio of 0.009 percentage points in column (1); if there is a spouse who works, the increment is only 0.004 percentage points. Lower savings for those with working spouses, conditional on income, is consistent with the presence of additional insurance through spousal labor supply; we discuss this further below. The wealth to income ratio rises and then falls with income; at the mean income in the sample, the effect is strongly positive. The savings propensity rises more steeply with age for higher income families.

Sensitivity to Wealth Measurement

As noted above, we have restricted our analysis of the SIPP data to financial assets, and we have excluded imputed values. The former restriction seems to us an important one given the arguments presented above about liquidity and consumption responses. Nevertheless, it is also useful to examine how our results are affected by moving to a broader measure of assets. Thus, in the first row of Table 6, we use as our wealth measure net financial assets plus retirement assets (in IRA or Keogh accounts)

\footnotetext{
${ }^{33}$ Note also that these findings are not inconsistent with those of Gruber (1994), whose sizeable consumption smoothing results implied that UI generosity increases were not simply crowding out other forms of consumption insurance (such as savings). Gruber finds that a 10 percentage point replacement rate rise increases consumption by 2.7 percent on an annualized basis, which is $10.7 \%$ during the 13.1 weeks of unemployment faced by the average worker who loses his job. Since a $10 \%$ replacement rate rise increases net (of the savings decline) resources by at least 4.7 to $8.0 \%$, this is a plausible consumption response.
} 
plus housing wealth. This represents the bulk of collateralizable wealth for most of the persons in our sample. ${ }^{34}$

In absolute value, the effect of unemployment insurance on this broader measure of wealth lies in between the response of gross and net assets shown in Table 5. In percentage terms, the effect is much smaller; this coefficient implies that a 10 percentage point rise in the replacement rate would lower broad asset holdings by only $0.5 \%$. The estimate, however, is very imprecise due to the noise which is introduced into the estimation by including other assets. Thus, we are unable to draw strong conclusions about the effect of UI on broader asset holdings. But the results do suggest that the effect of UI operates through financial assets only, so that the effect of the program on total wealth holdings is much smaller than the estimates of Table 5 imply. We return to this point in the conclusion.

We have also excluded from our analysis any observations with imputed information on wealth holdings, on the grounds that the relatively poor SIPP imputation procedure is unlikely to yield reasonable inferences for this population. Nevertheless, since this is not a random subsample of the population, by excluding them we may limit the applicability of our results to the entire population. In the next row of Table 6, therefore, we include the imputed observations in our regressions. The estimated coefficients are larger than those reported in Table 5. The means and medians of wealth are larger for this sample as well, however, so that in percentage terms these findings do not differ meaningfully from those in our basic regression models.

\section{Part VI: Extensions}

\section{A. Unemployment Risk}

An important implication of our model is that the savings effect of UI should rise with the amount

\footnotetext{
${ }^{30}$ The remaining major source of asset holdings is entrepreneurial assets. We are reticent to include these in our measure of personal wealth due to the criticisms of these SIPP data by Curtin et al. (1989)
} 
of unemployment risk faced by the individual. Unfortunately, testing this prediction is difficult because the unemployment risk faced by a given individual is likely to be correlated with other attributes of that individual. That is, the criticism that we levied earlier against measuring uncertainty based on job and individual characteristics applies equally well to assigning individual unemployment risks based on features such as industry and occupation. The problems with using such job characteristics to proxy for unemployment risk are highlighted by Murphy and Topel (1987) in a different context, the estimation of compensating differentials for unemployment.

This problem is potentially surmounted by using a more exogenous (to the individual) dimension of unemployment risk. A natural candidate is location-specific unemployment risk, under the assumption that mobility across broad locations is less endogenous to unemployment risk than is mobility across job types. $^{35}$ We incorporate location specific risk into the model by measuring the probability of being unemployed at a point in time in a worker's SMSA, averaged over the waves preceding and including the wealth interview. We do so using the Current Population Survey's Merged Outgoing Rotation Group (MORG) file, which provides monthly information on the employment status of approximately 150,000 workers; this large sample allows precise estimation of SMSA-specific unemployment rates over a four month (one wave) period. For workers whose SMSAs are not identified in the SIPP, we use the unemployment risk for the non-SMSA areas of their state of residence. ${ }^{36}$

\footnotetext{
${ }^{33}$ Returning to the context of estimating compensating wage differentials for unemployment, this parallels the strategy pursued by Adams (1985).

${ }^{36}$ Even if location provides exogenous assignment of unemployment risk, two potential problems remain with this approach. First, higher unemployment risk may be offset through other forms of compensation. If there is a pure wage compensating differential, then this will be captured through our detailed wage controls; but if the differential comes through more generous fringe benefits, this could affect wealth accumulation in an unobserved fashion. Second, a higher likelihood of unemployment causes a second-order positive correlation between UI and wealth through consumption smoothing: for those who actually lose their job, their wealth may fall less because UI is more generous. A potential solution to this problem is to focus only on those workers who do not lose their jobs. Using this group introduces an additional bias, however, since their probability of unemployment is most likely lower than average, so that the local unemployment risk will systematically overstate their unemployment risk. In
} 
In order to investigate the effect of unemployment risk, we augment equation (4) as follows:

$$
\begin{aligned}
\text { WEALTH }_{i}=\alpha+\beta_{1} X_{i}+\beta_{2} U_{i}+\beta_{3} U_{N E M}+\beta_{4} U_{N E M} * U_{i} & +\beta_{9} \delta_{j}+\beta_{6} \tau_{i}+\beta_{7} w_{i}^{*} \delta_{j} \\
& +\beta_{8} w_{i}^{*} \tau_{t}+\beta_{9} \sigma_{t}+\epsilon_{i j t}
\end{aligned}
$$

where UNEM is our measure of unemployment risk. If the effects of UI are stronger as unemployment risk rises, $\beta_{2}$ will be small, since it now measures the effect on those facing low unemployment risk, and $\beta_{4}$ will be large (in absolute value), since it measures the differential effect on those facing high unemployment risk. We have also included a full set of SMSA dummies $\left(\sigma_{a}\right)$; these control for any time invariant characteristics of particular locations which might be spuriously correlated with savings propensities.

Our findings are reported in the first panel of Table 7. In fact, we do see the hypothesized pattern. The main effect $\left(\beta_{2}\right.$, the coefficient on the replacement rate) is now close to zero in both specifications, while the interaction term $\left(\beta_{4}\right.$, the coefficient on the replacement rate times risk) is sizeable; it is only significant for net assets, however. That is, the crowdout effect on savings is largest for those individuals who face the greatest unemployment risk. The gross asset results imply that increase the level of unemployment risk from $2 \%$ to $4 \%$ would increase the crowdout effect of a $10 \%$ replacement rate rise from $0.23 \%$ of income to $0.29 \%$ of income. That is, a doubling in unemployment risk increases the crowdout due to UI by $27 \%$. For the net asset model, we find that the crowdout effect of a $10 \%$ replacement rate rise is $0.36 \%$ of income at a $2 \%$ unemployment risk, and is $0.63 \%$ of income at a $4 \%$ unemployment risk, so that the doubling in unemployment risk increases the crowdout by $75 \%$. Thus. the underlying level of unemployment risk is an important predictor of the crowd-out effects of UI.

A surprising feature of these specifications is that the positive main effect on the locid unemployment risk $\left(\beta_{3}\right)$ is smaller than the interaction term. This finding implies that current levels it UI generosity are sufficient to undo the increased savings response to local unemployment risk. An fact, our results are fairly similar if we exclude those who actually become unemployed. 
alternative explanation, however, is that the measurement error inherent in using local unemployment as a proxy for individual-specific unemployment risk is biasing our unemployment risk estimates towards zero. The net bias from such measurement error to the unemployment risk*UI interaction is unclear, so that the results using this noisy measure of unemployment risk are only suggestive. Nevertheless, the general pattern confirms our theoretical predictions.

\section{B. Life Cycle Effects}

As noted in the theory section, the life-cycle precautionary savings model yields the strong prediction that UI generosity will explain a higher fraction of savings for younger workers. We can test this supposition quite readily with our SIPP data. To do so, we run regressions of the form:

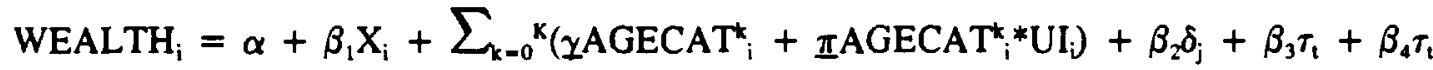

$$
\begin{aligned}
& +\beta_{5} w_{i}{ }^{*} \delta_{j}+\beta_{6} w_{i}^{*} \tau_{t}+\epsilon_{i}
\end{aligned}
$$

where AGECAT $_{i}$ is a dummy for individual $i$ being in age category $k$, up to $\mathbf{K}$ different monotonically increasing categories, and $\chi$ and $\underline{\pi}$ are vectors of coefficients on these dummies and their interactions with the replacement rate. We use four categories, following the simulations presented earlier: 25-34 years old; 35-44 years old; 45-54 years old; and 55-64 years old.

The results from this interacted regression are reported in the second panel of Table 7 . For gross assets, the coefficients do decline across the age distribution; for net assets, they are roughly constant. At the same time, however, wealth levels are rising with age, so that the relative effect of UI is falling sharply as individuals age for both measures of assets. In brackets under each of the estimates, we present the mean and median wealth to income ratio for each age group. Relative to either the mean or the median, the proportional effect of UI on savings is falling as individuals age, as predicted by the theory. Thus, our findings confirm the general prediction that precautionary savings for unemployment risk represents a smaller share of asset accumulation at older ages.

\section{Spousal Labor Supply}


Thus far, our analysis has focused solely on heads of household, and ignored working spouses. In fact, in our sample almost three-quarters of spouses work. This raises two important issues for the analysis. First, for those families with working spouses, we may mismeasure the net effect of the UI system on total family income risk by ignoring the insurance provided to secondary earners. Second, a natural source of insurance for unemployment risk is the labor supply of spouses. ${ }^{37}$ As a result, we would expect increases in UI generosity to have a smaller effect on married couples than on singles.

To extend our analysis to consider spousal labor supply, we first create a family replacement rate which is a weighted average of each spouse's replacement rates, where the weight is that spouse's average earnings. We then control for a quartic in a weighted average of spousal wages, and an interaction of this weighted average wage with time and state. Finally, we allow the effect of the replacement rate to differ for married and single heads, using the same type of interactive framework as in equation (6).

The results of this exercise are in the next panel of Table 7. The effect of UI on wealth holdings is significant for both married and single heads. We do find, however, that the effect of unemployment insurance is larger for single heads, which is consistent with the presence of insurance through spousal labor supply for married heads.

\section{Excluding Single Mothers}

One potential problem with our approach is that we have attributed our finding to differences in UI generosity across individuals. In fact, $\mathrm{UI}$ is only one element of the safety net provided by states, and savings should respond to all components of the state social insurance package. The two most important potential omitted programs are Workers' Compensation, which provides income support for on the job accidents, and Aid to Families with Dependent Children (AFDC), which provides cash welfare. By

\footnotetext{
${ }^{37}$ See Lundberg (1985) for direct evidence on the response of spousal labor supply to the unemployment of the household head. Note that "head" vs. "spouse" in our context is defined by the SIPP interviewing convention. In almost all cases, the man is labelled as the head for married couples. regardless of who is the primary income earner. This provides further motivation for using a tamily replacement rate, as described below.
} 
including state effects and state*wage interactions, fixed state differences in other social insurance program generosity will be controlled for. But correlated changes within states over time in these programs, may lead to omitted variables bias.

We are unable to fully differentiate the effects of UI and Workers' Comp in our results, although this distinction is addressed to some extent with our unemployment risk interaction model above. But we can differentiate the effects of AFDC, since eligibility for this program is largely restricted to single mothers. ${ }^{38}$ In the final panel of Table 7 , we exclude single mothers from our sample. In fact, the coefficients rise slightly relative to our findings in Table 5. This is consistent with the view that single mothers are less responsive to UI generosity, since there is another social insurance program on which they can rely if they lose their jobs.

\section{Conclusions}

Low rates of savings among individuals in the U.S. has led to extensive discussion among policymakers of alternative tax policies which can be used to stimulate savings. Largely absent from this discussion, however, is the important notion that current social insurance policies may substantially discourage savings. We have demonstrated theoretically and empirically that one such program, unemployment insurance, has important effects on individual savings behavior.

In terms of comparative statics, the predictions of our model and the results of our empirical analysis are quite consistent: UI crowds out individual savings, and this crowdout rises with the extent of unemployment risk and falls with age. In terms of magnitudes, however, the results are quite different. In the model, increasing the average replacement rate from 0.36 to 0.57 lowered asset/income ratios by 31 percent of income. In the empirical results, this same change is predicted to lower

${ }^{38}$ Some married couples can get AFDC under the AFDC-UP option, but this represented only $5 \%$,1: the caseload in 1990 (U.S. Committee on Ways and Means, 1992). 
asset/income ratios by only 0.7 to 1.9 percent of income.

There are several sources of the difference in these results. The first is that we only have one type of asset in the model, and it is fully liquid. In the empirical work, however, we have only modelled the effect of UI on financial assets, which represent a small share of total asset holdings. In a richer model which incorporated different types of assets with different degrees of liquidity, the response of financial assets only to UI generosity might be smaller than that predicted by our model.

The second is that we have ignored all other forms of insurance for unemployment in our modelling. While we noted earlier that there is evidence of less than full insurance for unemployment spells, there still may be partial insurance which mitigates the need for precautionary savings for the event of unemployment, through the labor supply of family members, transfers from extended family and friends, or other social insurance programs. This is evident in our empirical finding that the effects of UI are much stronger for single workers and weaker for female heads (who can rely on AFDC). Incorporating these other sources of insurance into our model would lower further the predicted response to UI generosity.

Third, it is important to highlight that the theoretical results pertain to comparing the steady-states for two separate regimes, for workers that have been existing under either regime for their entire lifecycle. A complementary simulation exercise would be to look at the saving effect of unexpectedly, but permanently, changing the UI benefit replacement at a specific age and then tracing the response to this policy shift. This type of policy simulation yields the same qualitative conclusions as those presented earlier, but the size of the effect is smaller than that found by comparing steady states. Empirically, part of the difference in UI generosity across individuals in our sample arises from permanent regime differences, but part arises from changes in UI policy over time. Thus, the correct comparison may not be to steady state differences but differences along a transition path.

Finally, we have not incorporated in the model the important underlying heterogeneity in savings 
behavior that we see in the data. While having fairly sizeable effects on the median worker in the model, the UI program may have much smaller effects on the aggregate capital stock, for two reasons. First, financial assets represent only a small part of the aggregate capital stock, and we are unable to demonstrate any effect of UI on other types of capital accumulation. Second, the median worker that we model in this paper only does a small share of aggregate savings. Most savings is done by higher income individuals whose income does not depend in an important way on the generosity of the UI system. Once again, this point can be addressed by extending models of this type to model the underlying differences in savings behavior across families of different income levels. The challenge is to find a theoretical basis for these differences, rather than to build them in ad-hoc; the means-tested welfare programs in Hubbard, Skinner, and Zeldes $(1994,1995)$ provides one rationale for the wider distribution of accumulated wealth.

At the same time that it lowers savings, unemployment insurance can raise welfare through completing the missing market for state-contingent insurance. Furthermore, this program has a host of other costs and benefits which must be considered in optimal program design, as discussed in Gruber (1994). The important point that this paper raises is that a critical input to such optimal benefit calculations is the potential welfare costs from reduced savings. Future research on this topic could usefully extend our findings to consider measurement of these welfare costs. 
References

Abel, Andrew B., "Precautionary Saving and Accidental Bequests," American Economic Review 75 (September 1985): 77-791.

Abowd, John M., and David Card, "Intertemporal Labor Supply and Long-Term Employment Contracts," American Economic Review 77 (March 1987): 50-68. ., "On the Covariance Structure of Earnings and Hours Change," Econometrica 57 (March 1989): 411-446.

Adams, J, "Permanent Differences in Unemployment and Permanent Wage Differentials," Quarterly Journal of Economics, 100 (1985), 29-50.

Aiyagari, S. Rao, "Uninsured Idiosyncratic Risk and Aggregate Saving," Quarterly Journal of Economics 109 (August 1994a): 659-684.

Altonji, Joseph and Aloysius Siow, "Testing the Response of Consumption to Income Changes with (Noisy) Panel Data," Quarterly Journal of Economics 102 (May 1987): 293-328.

Atkeson, Andrew and Robert E. Lucas, Jr., "Efficiency and Equality in a Simple Model of Efficient Unemployment Insurance," Journal of Economic Theory 66 (June 1995): pp.64-88.

Baily, Martin Neil, "Some Aspects of Optimal Unemployment Insurance" Journal of Public Economics, 10 (1978): 379-402.

Berk, R. A., "A Primer on Robust Regression," in J. Fox and J. S. Long, eds, Modern Methods of Data Analysis. Newbury Park, CA: Sage Publications, 1990.

Browning, Martin and Annamaria Lusardi, "Household Saving: Micro Theories and Micro Facts," mimeo, April 1995.

Caballero, Ricardo J., "Earnings Uncertainty and Aggregate Wealth Accumulation," American Economic Review, 81 (1991): 859-871.

Carroll, Christopher, "Buffer Stock Saving and the Permanent Income Hypothesis," mimeo, Board of Governors of the Federal Reserve System, 1993.

., "How Does Future Income Affect Current Consumption?" Quarterly Journal of Economics 109 (February 1994): 111-148.

., and Andrew Samwick, "How Important is Precautionary Saving?" mimeo, Board of Governors of the Federal Reserve System, 1993.

., "The Nature and Magnitude of Precautionary Wealth," mimeo, Board of Governors of the Federal Reserve System, 1994. 
Cochrane, John H. "A Simple Test of Consumption Insurance", Journal of Political Economy, 99 (1991): 957-976.

Curtin, Richard T., F. Thomas Juster, and James N. Morgan, "Survey Estimates of Wealth: An Assessment of Quality," in Robert E. Lipsey and Helen S. Tice, eds., The Measurement of Saving, Investment, and Wealth. Chicago: University of Chicago Press, 1989.

Dardanoni, Valentino, "Precautionary Savings Under Income Uncertainty: A Cross-Sectional Analysis," Applied Economics, 23 (1991): 153-160.

Davidson, Carl and Stephen Woodbury, "Optimal Unemployment Insurance," mimeo, 1995.

Deaton, Angus, "Saving and Liquidity Constraints," Econometrica 59 (1991): 1221-1248. ., Understanding Consumption, Oxford: Oxford University Press, 1992.

Diamond, Peter, "A Framework for Social Security Analysis," Journal of Public Economics, 8 (1977), 275-298.

Duncan, Gary J., and Daniel H. Hill, "An Investigation of the Extent and Consequences of Measurement Error in Labor-Economic Survey Data," Journal of Labor Economics 3 (1985): 508-532.

Dynan, Karen E., "How Prudent Are Consumers?," Journal of Political Economy, 101 (1993), 11041113.

Easley, David, Nicholas Kiefer, and Uri Possen, "An Equilibrium Analysis of Optimal Unemployment Insurance and Taxation," Quarterly Journal of Economics 100 (suppl., 1985): 989-1010.

Employment and Training Administration (various years). "Significant Provisions of State Unemployment Insurance Laws". Washington, D.C.: U.S. Department of Labor.

Engen, Eric, "A Stochastic Life-Cycle Model with Mortality Risk: Estimation with Panel Data." Mimeo, UCLA, 1993a.

., "Consumption and Savings in a Life-Cycle Model with Stochastic Earnings and Mortality Risk." Mimeo, UCLA, $1993 b$.

Fishback, Price V., and Shawn Everett Kantor, "Insurance Rationing and the Origins of Workers' Compensation". NBER Working Paper \#4943, December 1994.

Fisher, Malcolm, "Exploration in Savings Behavior," Oxford University Institute Statistics Bulletin 18 (August 1956): 201-277.

Fleming, J.S., "Aspects of Optimal Unemployment Insurance: Search, Leisure, Savings, and Capital Market Imperfections," Journal of Public Economics 10 (December 1978): 403-425. 
Friedman, Milton, A Theory of the Consumption Function, Princeton: Princeton University Press, 1957

Gruber, Jonathan, "The Consumption Smoothing Benefits of Unemployment Insurance," NBER Working Paper \#4750, May 1994.

Guiso, Luigi, Tullio Jappelli, and Daniele Terlizzese, "Earnings Uncertainty and Precautionary Savings," Journal of Monetary Economics, 30 (1992): 307-337.

., "Income Risk, Borrowing Constraints and Portfolio Risk," CEPR Discussion Paper No. 888, January 1994.

Guiso, Luigi and Tullio Jappelli, "Does Uninsurable Uncertainty Increase the Demand for Insurance against Insurable Risks?" mimeo, 1994.

Hamermesh, Daniel S., "Social Insurance and Consumption: An Empirical Inquiry." American Economic Review, 72 (1982): 101-113.

Hansen, Gary D., and Ayse Imrohoroglu, "The Role of Unemployment Insurance in an Economy with Liquidity Constraints and Moral Hazard," Journal of Political Economy 100 (February 1992): 118-142.

Hoynes, Hilary, Michael Hurd and Harish Chand, "Imputed Wealth, Subjective Survival Probabilities, and Social Security Wealth," Mimeo, NBER, May 1995.

Hubbard, R. Glenn and Kenneth L. Judd, "Social Security and Individual Welfare: Precautionary Saving, Liquidity Constraints, and the Payroll Tax," American Economic Review, 77 (September 1987), 630-646.

Hubbard, R. Glenn, Jonathan Skinner, and Stephen P. Zeldes, "The Importance of Precautionary Motives in Explaining Individual and Aggregate Saving," Carnegie-Rochester Conference Series on Public Policy 40 (June 1994): 59-126.

Hubbard, R. Glenn, Jonathan Skinner, and Stephen P. Zeldes, "Precautionary Saving and Social Insurance," Journal of Political Economy 103 (April 1995): 360-399.

Hurd, Michael, "Mortality Risk and Bequests," Econometrica 57 (1989): 779-814.

Kazarosian, Mark "Precautionary Savings--A Panel Study," mimeo, 1994.

Kimball, Miles, "Precautionary Saving in the Small and in the Large," Ecconometrica 58 (1990): 5373.

Kotlikoff, Laurence J., "Health Expenditures and Precautionary Saving," in L. Kotlikoff, ed., What Determines Saving? Cambridge: MIT Press, 1988.

., John Shoven, and Avia Spivak, "Annuity Markets, Savings, and the Capital Stock," in Z. Bodie, John Shoven, and David Wise, eds., Issues in Pension Economics, Chicago: 
University of Chicago Press, 1987.

Levin, Laurence, "Demand for Health Insurance and Precautionary Motives for Savings among the Elderly," Lournal of Public Economics 57 (July 1995): pp. 337-368.

Levine, Phillip B. (1990). "Unemployment Insurance Benefit and Tax Schedules, 1978-1987". Mimeo, Princeton University.

Lillard, Lee A., and Robert J. Willis, "Dynamic Aspects of Earnings Mobility," Econometrica 46 (September 1978): 985-1012.

Lundberg, Shelley, "The Added Worker Effect," Journal of Labor Economics, 1 (1985): 11-37.

Lusardi, Annamaria, "Precautionary Saving and Subjective Earnings Variance," Center for Economic Research, 1993.

MaCurdy, Thomas E., "The Use of Time Series Processes to Model the Error Structure of Earnings in a Longitudinal Data Analysis," Journal of Econometrics 18 (1982): 83-114.

Meyer, Bruce D., "Unemployment Insurance and Unemployment Spells," Econometrica 58 (July 1990): 757-782.

Mortensen, Dale, "A Welfare Analysis of Unemployment Insurance: Variations on Second-Best Themes," Carnegie-Rochester Conference Series on Public Policy 19 (Autumn 1983): 67-97.

Murphy, Kevin M., and Robert H. Topel, "Unemployment, Risk, and Earnings: Testing for Equalizing Wage Differences in the Labor Market," in Kevin Lang and Jonathan S. Leonard, eds. Unemployment and the Structure of Labor Markets. New York: Basil Blackwell, 1987.

Nelson, Julie, "On Testing for Full Insurance Using Consumer Expenditure Survey Data," Journal of Political Economy 102 (April 1994): 384-394.

Palumbo, Michael, "The Effects of Income Uncertainty on Saving and Insurance Purchases: Evidence from a Survey of Maine's Workers, 1890," mimeo, 1992.

Runkle, David E., "Liquidity Constraints and the Permanent Income Hypothesis: Evidence from Panel Data," mimeo, Federal Reserve Bank of Minneapolis, November 1988.

Samwick, Andrew, "The Limited Offset Between Pension Wealth and Other Private Wealth: Implications of Buffer-Stock Saving," mimeo, 1994.

Sandmo, Agnar, "The Effect of Uncertainty on Saving Decisions," Review of Economic Studies 37 (1970): 353-360.

Shavell, Steven and Laurence Weiss, "The Optimal Payment of Unemployment Insurance Benefits over Time," Journal of Political Economy 87 (December 1979): 1347-1362.

Sheshinski, E. and Yoram Weiss, "Uncertainty and Optimal Social Security Systems," Quarterly 
Journal of Economics 96 (1981): 189-206.

Skinner, Jonathan, "Variable Lifespan and the Intertemporal Elasticity of Consumption," Review of Economics and Statistics 67 (November 1985): 616-623.

., "Risky Income, Life Cycle Consumption, and Precautionary Saving," Journal of Monetary Economics 22 (September 1988): 237-255.

Starr-McCluer, Martha, "Health Insurance and Precautionary Saving," mimeo, Federal Reserve Board, 1994.

Topel, Robert, "On Layoffs and Unemployment Insurance", American Economic Review, 73 (1983): 541-559.

U.S. Committee on Ways and Means, Green Book 1992: Background Material on Programs Under the Jurisdiction of the Committee on Ways and Means, Washington D.C.: GPO, 1992

Walker, James R. 1993. "Migration Among Low-Income Households: Helping the Witch Doctors Reach Consensus," mimeo, University of Wisconsin-Madison, 1993.

Zeldes, Stephen P., "Optimal Consumption with Stochastic Income: Deviations form Certainty Equivalence," Quarterly Journal of Economics 104 (May 1989): 275-298.

., "Consumption and Liquidity Constraints: An Empirical Investigation," Journal of Political Economy 97 (April 1989): 305-346. 
Table 1: Effects of Unemployment Insurance

on Asset Accumulation and Consumer Welfare

\begin{tabular}{|c|c|c|c|c|}
\hline \multirow[b]{2}{*}{ Parameters } & \multirow{2}{*}{$\begin{array}{c}\text { Without UI } \\
\text { Median } \\
\text { Asset/Inc } \\
\text { Ratio }\end{array}$} & \multicolumn{3}{|c|}{ With UI } \\
\hline & & $\begin{array}{c}\text { Median } \\
\text { Asset/Inc } \\
\text { Ratio }\end{array}$ & $\begin{array}{c}\Delta \\
\text { Asset/Inc }\end{array}$ & $\begin{array}{c}\% \Delta \\
\text { consumer } \\
\text { welfare }\end{array}$ \\
\hline Initial (PE) & 3.61 & 2.25 & -1.36 & 8.3 \\
\hline$\gamma=2$ & 3.07 & 1.86 & -1.21 & 4.9 \\
\hline$\gamma=3$ & 3.92 & 2.48 & -1.44 & 17.9 \\
\hline$\delta=0.06$ & 3.30 & 1.94 & -1.36 & 8.8 \\
\hline$\delta=0.04$ & 3.94 & 2.61 & -1.35 & 8.7 \\
\hline$(1-p 1)=.04$ & 3.97 & 2.56 & -1.41 & 9.8 \\
\hline \multirow[t]{2}{*}{$(1-p 1)=.02$} & 3.20 & 1.94 & -1.26 & 5.3 \\
\hline & $\begin{array}{l}\text { Aggregate Asse } \\
\text { Income }\end{array}$ & & & \\
\hline General Equilibrium & 3.79 & 3.30 & -.49 & 2.6 \\
\hline
\end{tabular}

Note: This table compares steady-states. $\mathrm{PE}=$ partial equilibrium. $\mathrm{GE}=$ general equilibrium. Except for the last row, all steady-states are $\mathrm{PE}$. The \% change in consumer welfare is calculated as an equivalent variation measure of the mean change in consumer welfare as a percentage of mean expected lifetime income. Initial Parameters for Baseline Simulations of the Model: risk aversion coefficient $(\gamma)=2.5$; time preference rate $(\delta)=0.05$ (annual rate); maximum lifespan $(D)=75$ years old; variance of $\log$ earnings innovations $\left(\sigma_{e}^{2}\right)=0.05$ (annual); AR(1) coefficient $(\rho)=0.85$; employment/unemployment probabilities: $\mathrm{p} 0=.35, \mathrm{pl}=.97$; income tax rate on income $\left(\tau^{y}, \tau\right)=0.3$; sales tax $=0.04$; initial UI payroll tax $=0.083$; initial real net return $=0.035$ (annual); UI benefit formula rate $(\theta)=0.5$; $\min$ UI benefit $=\$ 325 /$ qtr; $\max$ UI benefit $=\$ 3,900 /$ qtr; initial average benefit $\pi=0.46$; UI payroll tax earnings limit $(\bar{Y})=\$ 7,000$; UI benefits received for 2 periods $(1 / 2$ year $)$. 
Table 2: Effects of Unemployment Insurance

on Asset Accumulation across Age

\begin{tabular}{|c|c|c|c|}
\hline & Without UI & With UI & \\
\hline Age & $\begin{array}{c}\text { Median } \\
\text { Asset/Inc } \\
\text { Ratio }\end{array}$ & $\begin{array}{c}\text { Median } \\
\text { Asset/Inc } \\
\text { Ratio }\end{array}$ & $\begin{array}{c}\Delta \\
\text { Asset/Inc }\end{array}$ \\
\hline $25-34$ & 1.12 & 0.48 & -0.64 \\
\hline $35-44$ & 2.39 & 1.26 & -1.13 \\
\hline $45-54$ & 4.15 & 2.80 & -1.35 \\
\hline $55-65$ & 5.96 & 4.66 & -1.30 \\
\hline
\end{tabular}

Note: Initial parameters are described in the note to Table 1.

Table 3: Effects of Alternative Unemployment Insurance Program Structure on the Saving Rate, Capital Stock, and Consumer Welfare

\begin{tabular}{cccccc}
\hline \hline & $\begin{array}{c}\text { Median } \\
\text { Asset/Inc } \\
\text { Ratio }\end{array}$ & $\begin{array}{c}\Delta \\
\text { Asset/Inc } \\
\text { Ratio }\end{array}$ & $\begin{array}{c}\% \Delta \\
\text { consumer } \\
\text { welfare }\end{array}$ & $\begin{array}{c}\text { Average } \\
\text { UI Replace } \\
\text { Rate }\end{array}$ & $\begin{array}{c}\text { UI } \\
\text { Tax } \\
\text { Rate }\end{array}$ \\
$\begin{array}{c}\theta=.60 \\
2.25\end{array}$ & $\cdots$ & $\cdots$ & 0.47 & 8.2 \\
$\theta=.40$ & 2.10 & -0.15 & 0.7 & 0.57 & 9.3 \\
$\begin{array}{c}\text { Benefial } \\
\text { 1 Year }\end{array}$ & 2.41 & 0.16 & -0.8 & 0.36 & 7.7 \\
$\begin{array}{c}\text { Benefit Duration } \\
\text { 1 Quarter }\end{array}$ & 1.98 & -0.27 & 1.1 & 0.47 & 12.0 \\
\hline \hline
\end{tabular}

Note: The UI payroll tax rate $\left(\tau^{p}\right)$ is determined endogenously to satisfy the government budget constraint. Initial parameters described in note to Table 1. 
Table 4A: Means of SIPP Covariates

\begin{tabular}{cc}
\hline \hline Age & 40.55 \\
Female & $(10.32)$ \\
Years of Education & 0.240 \\
White & 13.37 \\
Married & $(2.96)$ \\
Spouse's Education & 0.873 \\
(if married) & 0.684 \\
Number of Kids & 12.78 \\
& $(2.86)$ \\
Spouse Worked & 0.99 \\
(if married) & $(1.16)$ \\
Real Weekly Wage & 0.744 \\
Real Family Income & 417.8 \\
& $(232.4)$ \\
After SS Tax & 31,181 \\
Replacement Rate & $(17,567)$ \\
Number of Obs & 0.436 \\
\hline \hline
\end{tabular}

Note: Based on authors' tabulations of '84-'90 SIPP data. Standard deviations in parentheses. 
Table 4B: Distribution of SIPP Wealth Data

\begin{tabular}{|c|c|c|c|c|}
\hline \multicolumn{5}{|c|}{ Without Imputed Values } \\
\hline & Gross & Net & Gross/Inc & Net/Inc \\
\hline Mean & $\begin{array}{c}10229 \\
(49429)\end{array}$ & $\begin{array}{c}7625 \\
(47992)\end{array}$ & $\begin{array}{c}0.251 \\
(0.673)\end{array}$ & $\begin{array}{c}0.166 \\
(0.761)\end{array}$ \\
\hline 10th \% ile & 0 & -4229 & 0 & -0.175 \\
\hline 25th \% ile & 232 & -1177 & 0.010 & -0.050 \\
\hline 50th \% ile & 1614 & 325 & 0.056 & 0.014 \\
\hline 75th \%ile & 7418 & 5786 & 0.218 & 0.178 \\
\hline 90th \% ile & 24297 & 22413 & 0.657 & 0.622 \\
\hline Number of Obs & 24903 & 23162 & 24093 & 23162 \\
\hline \multicolumn{5}{|c|}{ With Imputed Values } \\
\hline & Gross & Net & Gross/Inc & Net/Inc \\
\hline Mean & $\begin{array}{c}12974 \\
(52089)\end{array}$ & $\begin{array}{c}7625 \\
(47992)\end{array}$ & $\begin{array}{c}0.308 \\
(0.810)\end{array}$ & $\begin{array}{c}0.215 \\
(0.859)\end{array}$ \\
\hline 10th \%ile & 0 & -4301 & 0 & -0.172 \\
\hline 25th \%ile & 303 & -1175 & 0.013 & -0.048 \\
\hline 50th \%ile & 2166 & 654 & 0.071 & 0.024 \\
\hline 75th \%ile & 9667 & 8017 & 0.279 & 0.232 \\
\hline 90th \%ile & 31767 & 29665 & 0.809 & 0.757 \\
\hline Number of Obs & 33434 & 33434 & 33434 & 33434 \\
\hline
\end{tabular}

Note: Based on authors' tabulations of '84-'90 SIPP data. Standard deviations in parentheses. First panel shows results excluding observations where some element of wealth has been imputed by the SIPP; the second panel includes these observations. 
Table 5: Basic Results

\begin{tabular}{|c|c|c|}
\hline & $\begin{array}{c}(1) \\
\text { Gross/Income }\end{array}$ & $\begin{array}{c}(2) \\
\text { Net/Income }\end{array}$ \\
\hline $\begin{array}{l}\text { Replacement } \\
\text { Rate }\end{array}$ & $\begin{array}{r}-0.0349 \\
(0.0125)\end{array}$ & $\begin{array}{c}-0.0927 \\
(0.0274)\end{array}$ \\
\hline Age & $\begin{array}{l}-0.0014 \\
(0.0004)\end{array}$ & $\begin{array}{l}-0.0034 \\
(0.0009)\end{array}$ \\
\hline $\begin{array}{c}\text { Age Squared } \\
\left({ }^{*} 100\right)\end{array}$ & $\begin{array}{c}0.0021 \\
(0.0005)\end{array}$ & $\begin{array}{c}0.0056 \\
(0.0011)\end{array}$ \\
\hline $\begin{array}{l}\text { Years of } \\
\text { Education }\end{array}$ & $\begin{array}{c}0.0029 \\
(0.0002)\end{array}$ & $\begin{array}{c}0.0013 \\
(0.0005)\end{array}$ \\
\hline Female & $\begin{array}{c}0.0031 \\
(0.0016)\end{array}$ & $\begin{array}{l}-0.0129 \\
(0.0035)\end{array}$ \\
\hline Married & $\begin{array}{c}-0.0138 \\
(0.0033)\end{array}$ & $\begin{array}{c}-0.0192 \\
(0.0072)\end{array}$ \\
\hline White & $\begin{array}{c}0.0115 \\
(0.0016)\end{array}$ & $\begin{array}{c}0.0160 \\
(0.0034)\end{array}$ \\
\hline Spouse's Ed. & $\begin{array}{c}0.0018 \\
(0.0002)\end{array}$ & $\begin{array}{c}0.0014 \\
(0.0005)\end{array}$ \\
\hline Number of Kids & $\begin{array}{c}-0.0059 \\
(0.0005)\end{array}$ & $\begin{array}{c}-0.0102 \\
(0.0011)\end{array}$ \\
\hline Spouse Works & $\begin{array}{l}-0.0044 \\
(0.0015)\end{array}$ & $\begin{array}{l}-0.0180 \\
(0.0034)\end{array}$ \\
\hline $\begin{array}{c}\text { Income } \\
\left({ }^{*} 10^{4}\right)\end{array}$ & $\begin{array}{c}0.0119 \\
(0.0016)\end{array}$ & $\begin{array}{c}0.0152 \\
(0.0036)\end{array}$ \\
\hline $\begin{array}{l}\text { Income } \\
\left({ }^{*} 10^{19}\right)\end{array}$ & $\begin{array}{l}-0.0758 \\
(0.0115)\end{array}$ & $\begin{array}{l}-0.0996 \\
(0.0256)\end{array}$ \\
\hline $\begin{array}{c}\text { Income } * \text { Age } \\
(* 107)\end{array}$ & $\begin{array}{c}0.0569 \\
(0.0298)\end{array}$ & $\begin{array}{c}0.0188 \\
(0.0065)\end{array}$ \\
\hline Number of Obs & 24903 & 23162 \\
\hline
\end{tabular}

Note: Standard errors in parentheses. Regression also includes a quartic in wages, a full set of panel dummies and state dummies, interactions between year dummies and weekly wages, and interaction between state dummies and weekly wages. 
Table 6: Sensitivity to Asset Measures

\begin{tabular}{|c|c|c|c|}
\hline & $\begin{array}{c}\text { (1) } \\
\text { Gross/Income }\end{array}$ & $\begin{array}{c}(2) \\
\text { Net/Income }\end{array}$ & $\begin{array}{c}(3) \\
\text { (Net }+ \text { Ret. Assets }+ \\
\text { Housing)/Income }\end{array}$ \\
\hline $\begin{array}{c}\text { Broader Measure } \\
\text { of Assets }\end{array}$ & & & $\begin{array}{l}-0.051 \\
(0.134)\end{array}$ \\
\hline Number of Obs & & & 21164 \\
\hline $\begin{array}{l}\text { Including Imputed } \\
\text { Values }\end{array}$ & $\begin{array}{l}-0.061 \\
(0.014)\end{array}$ & $\begin{array}{c}-0.121 \\
(0.026)\end{array}$ & \\
\hline Number of Obs & 33434 & 33434 & \\
\hline
\end{tabular}

Note: Standard errors in parentheses. Each row reports the coefficient on the replacement rate from a separate regression which also includes the control variables listed in the Table 5 and the note to that Table. 
Table 7: Extensions

\begin{tabular}{|c|c|c|}
\hline & $\begin{array}{c}(1) \\
\text { Gross/Income }\end{array}$ & $\begin{array}{c}(2) \\
\text { Net/Income }\end{array}$ \\
\hline \multicolumn{3}{|c|}{ Unemployment Risk Interactions } \\
\hline Repl Rate & $\begin{array}{r}-0.016 \\
(0.023)\end{array}$ & $\begin{array}{r}-0.009 \\
(0.050)\end{array}$ \\
\hline $\begin{array}{c}\text { Local Unem } \\
\text { Risk }\end{array}$ & $\begin{array}{c}0.142 \\
(0.152)\end{array}$ & $\begin{array}{c}0.639 \\
(0.328)\end{array}$ \\
\hline RR*Local Unemp & $\begin{array}{l}-0.328 \\
(0.307)\end{array}$ & $\begin{array}{l}-1.340 \\
(0.664)\end{array}$ \\
\hline \multicolumn{3}{|c|}{ Age Interactions } \\
\hline $\begin{array}{c}\text { RR* } \\
25-34 \text { Years Old }\end{array}$ & $\begin{array}{l}-0.047 \\
(0.014) \\
{[0.134\}} \\
\{0.035\}\end{array}$ & $\begin{array}{c}-0.112 \\
(0.030) \\
{[0.026]} \\
{[0]}\end{array}$ \\
\hline $\begin{array}{c}\text { RR* } \\
35-44 \text { Years Old }\end{array}$ & $\begin{array}{c}-0.034 \\
(0.014) \\
{[0.209\}} \\
\{0.054\}\end{array}$ & $\begin{array}{l}-0.063 \\
(0.030) \\
{[0.121]} \\
\{0.011\}\end{array}$ \\
\hline $\begin{array}{c}\text { RR }^{*} \\
45-54 \text { Years Old }\end{array}$ & $\begin{array}{l}-0.019 \\
(0.015) \\
{[0.326]} \\
\{0.083\}\end{array}$ & $\begin{array}{l}-0.094 \\
(0.032) \\
{[0.247]} \\
\{0.043\}\end{array}$ \\
\hline $\begin{array}{c}\text { RR* } \\
55-64 \text { Years Old }\end{array}$ & $\begin{array}{c}-0.009 \\
(0.016) \\
{[0.545]} \\
\{0.172\}\end{array}$ & $\begin{array}{c}-0.114 \\
(0.036) \\
{[0.501]} \\
\{0.140\}\end{array}$ \\
\hline
\end{tabular}


Table 7: Extensions, Continued

\begin{tabular}{ccc}
\hline \hline & $(1)$ & $(2)$ \\
& Gross/Income & Net/Income \\
\hline RR* $^{*}$ & Marital Status Interactions & \\
Single & -0.062 & -0.126 \\
& $(0.014)$ & $(0.030)$ \\
& {$[0.255]$} & {$[0.161]$} \\
RR* & $\{0.041\}$ & $\{0.006\}$ \\
Married & -0.028 & -0.080 \\
& $(0.012)$ & $(0.027)$ \\
& {$[0.249]$} & {$[0.162]$} \\
& $\{0.064\}$ & $\{0.019\}$ \\
\hline Replacement Rate & Excluding Female Heads & \\
& -0.038 & -0.103 \\
& $(0.015)$ & $(0.030)$ \\
\hline \hline
\end{tabular}

Note: Standard errors in parentheses; group-specific means in [] and medians in \{\}. Each panel reports the coefficients on the replacement rate and its interactions from separate regressions which also includes the control variables listed in the Table 5 and the note to that Table. 


\section{Appendix A}

\section{A. Mean, Expected Age-Earnings Profile}

The specification of the human capital adjustment factor determines an individuals expected ageearnings profile, and is based on the empirical estimation of a log earnings regression equation using panel data on labor earnings for employed heads of households and spouses (when present) that are high school graduates, using the Panel Study of Income Dynamics from 1982 to 1986 (Engen, 1993b). We find that $\mathrm{z}_{\mathrm{q}}$ is increasing until peaking at age 46 and then decreasing until retirement at age 65 . The mean ageearnings profile for consumers exhibits approximately the same profile as $z_{t}$ since labor supply, $h$, is a fixed constant and the wage rate, $w_{t}$, grows at a constant rate, $g$, (reflecting productivity growth) in a steady state. The quarterly pattern of wages is set to be a piece-wise linear function of the annual wage regression.

B. Stochastic Process for Wages

The stochastic process for log labor earnings is expressed as:

$$
y_{t}=\bar{y}_{1}+u_{1}
$$

where the realized log of labor earnings, $y_{t}$, is the sum of the mean of log net earnings, $\bar{y}_{t}$, and an error term, $u_{\text {. }}$ To capture the persistence of observed earnings shocks over time, the error structure for the log of labor earnings is specified as an AR(1) process:

$$
u_{t}=\rho u_{t-1}+e_{t}
$$

where $a_{1}$ is normally distributed; $a_{1} \sim N\left(0, \sigma_{*}^{2}\right)$.

Empirical studies by Lillard and Willis (1978), MaCurdy (1982), Abowd and Card (1989, 1991), Hubbard, Skinner, and Zeldes (1994), and Carroll and Samwick (1995) provide estimates of the stochastic process for earnings (or the covariance structure of earnings from which a stochastic process can be derived) using survey data from the Panel Study of Income Dynamics (PSID). But Duncan and Hill 
(1985) and Altonji and Siow (1986) find evidence that measurement error for reported earnings in the PSID is a problem for inferring this process. Reporting error should be less of a problem with administrative earnings data collected from W-2 tax returns. Engen (1993b) analyzes the covariance structure of earnings reported on W-2 statements included with tax returns, and finds that an AR(1) process best describes the stochastic structure of income shocks. Estimates for the parameters $\rho$ and $\sigma_{e}^{2}$ are $\hat{\rho}=0.82$ and $\hat{\gamma}_{e}^{2}=0.05$ for joint tax returns, and $\hat{\rho}=0.92$ and $\hat{\sigma}_{e}^{2}=0.10$ for individual tax returns. For the UI policy simulations $\rho$ is set equal to 0.85 and $\sigma_{a}^{2}$ is set equal to 0.05 (on an annual basis, or .003 on a quarterly basis). These are conservative values for the variance and persistence of shocks to income compared to these other studies.

C. Model Solution

During the retirement phase of the life-cycle, Social Security benefits and asset income are nonstochastic so optimal consumption can be calculated analytically for any wealth level, $\mathrm{W}_{\mathrm{l}}$, at any age $t=R, \ldots, D$, by:

$$
C_{t}=\left[W_{t}+\sum_{i=t+1}^{D} P_{i}\right] H_{t}
$$

where

$$
H_{t}=(1+\tau) \sum_{j=t}^{D}\left[\frac{\left[(1+\delta)^{t-j} \prod_{k=t}^{j}\left(1+r_{k}^{*}\right)\right]^{1 / \gamma}}{\prod_{k=t}^{j}\left(1+r_{k}^{*} \gamma^{-t}\right.}\right] .
$$

During the working phase of the life-cycle, $t=1, \ldots R-1$, with stochastic income and constant relative risk aversion utility, the optimal consumption/saving problem cannot be solved analytically, but only described by the Euler conditions: 


$$
U_{c}\left(C_{l}\right)=\frac{\left(1+r_{t}^{*}\right)}{(1+\delta)} E_{t} U_{c}\left(C_{t+1}\right) \quad \forall t=1, \ldots,(R-1)
$$

where $U_{c}$ represents the marginal utility of consumption. A numerical algorithm is used to solve for optimal consumption and saving. The general idea is to discretize the wealth and income state space--age and employment status are already discrete--and then use the wealth transition equation and the Euler equation to solve the consumption/saving problem recursively backwards. Values of consumption for wealth and income levels between the discrete steps are linearly interpolated. For instance, the Euler equation is solved at age $t(\forall t=1, \ldots, R-1)$ by numerically searching for a value of $C_{t}$ that solves the Euler equation conditional on the state variables $W_{v}, Y_{t}$, and $S_{v}$. The expected marginal utility of optimal next period consumption, $C_{t+1}$, is integrated numerically as a function of expected wealth, $W_{t+1}$, income, $Y_{t+1}$, and employment status, $S_{t+1}$, in period $t+1$, using the wealth transition equation and the stochastic processes for employment and earnings. Optimal values of $\mathrm{C}_{\mathrm{t}}$ are found for different discrete levels of $W_{t}, S_{t}$, and $Y_{1}$, over plausible ranges, and optimal consumption is approximated for levels of wealth and income between these levels. The procedure is repeated for period $t-1$ and the algorithm continues back inductively to the initial period. The result is a numerically approximated consumption function that is a function of a four-dimensional grid of state variables; wealth, $W_{t}$, current labor income, $Y_{t}$, employment status, $S_{t}$, and age, $t$.

A random number generator is used to simulate (log) labor income shocks from a normal distribution, so that a realized labor income path is projected for an individual. For a given realization of earnings, an individual's corresponding lifetime consumption and saving decisions are calculated. This procedure is repeated for a large number of individuals, $\mathrm{N}$, in a given cohort, who each receive different shocks from the same distribution, and thus end up with different realized lifetime earnings profiles. Reported calculations are for $\mathbf{N}=7,000$. Calculating the sample medians, or means, for each age gives a representative age profile for consumption, wealth, earnings, and saving. 
D. General Equilibrium

This section presents the production side of this closed-economy model. The production side of the economy is described quite simply by an instantaneous CES production function:

$$
Q_{t}^{\alpha \beta}=\psi\left[\beta\left[(1+g)^{t} L_{t}^{\alpha \delta}\right]^{\left(1-\frac{1}{a}\right)}+(1-\beta)\left(K_{t}^{\alpha \beta}\right)^{\left(1-\frac{1}{\alpha}\right)}\right]\left(\frac{a}{\alpha-1}\right)
$$

where $Q_{t}^{\text {st }}$ is aggregate output produced in period $t$ (which is consumed, saved, or taxed to provide a government good), $\mathrm{L}_{\mathrm{l}}^{\mathrm{at}}$ and $\mathrm{K}_{\mathrm{t}}^{\mathrm{k}}$ are aggregate labor and capital used in production, $\mathrm{g}$ is the exogenous rate of labor productivity growth (set equal to 0.25 percent), $\psi$ is a scaling parameter, $\beta$ is a parameter indicating labor intensity in production (set equal to 0.75 , which is labor's share of total income), and $\alpha$ is a parameter that represents the elasticity of substitution between capital and labor (set equal to 1 ).

Profit maximizing choices of input utilization and output production by firms in period $t$ yield the conditions for the return to capital, $r_{t}$, and the gross wage rate, $w_{t}$. The equilibrium return to capital and the return to labor are determined endogenously by iterating on these factor prices, with an endogenous income tax structure and UI payroll tax, until they are set such to clear the labor and capital markets and the government budget constraint. In a steady state equilibrium, wages and per capita output grow at the rate of productivity growth, $\mathrm{g}$, and the rate of return to capital is constant. 